\title{
P2X $\mathrm{X}_{2}$ R Purinergic Receptor Subunit mRNA and Protein Are Expressed by All Hypothalamic Hypocretin/Orexin Neurons
}

\author{
FULVIO FLORENZANO, ${ }^{1}$ MARIA TERESA VISCOMI, ${ }^{1}$ VALENTINA MERCALDO,${ }^{1,2}$ \\ PATRIZIA LONGONE, ${ }^{1}$ GIORGIO BERNARDI, ${ }^{1,3}$ CLAUDIA BAGNI,, 2 \\ MARCO MOLINARI, ${ }^{*}$ AND PASCAL CARRIVE ${ }^{4}$ \\ ${ }^{1}$ I.R.C.C.S. Santa Lucia Foundation, I-00179 Rome, Italy \\ ${ }^{2}$ Department of Biology, University of Rome Tor Vergata, I-00133 Rome, Italy \\ ${ }^{3}$ Department of Neurology, University of Rome Tor Vergata, I-00133 Rome, Italy \\ ${ }^{4}$ Department of Anatomy, School of Medical Sciences, University of New South Wales, \\ Sydney, New South Wales, 2052, Australia
}

\begin{abstract}
Neurophysiologic data suggest that orexin neurons are directly excited by ATP through purinergic receptors (P2XR). Anatomical studies, though reporting P2XR in the hypothalamus, did not describe it in the perifornical hypothalamic area, where orexinergic neurons are located. Here we report the presence of the $\mathrm{P}_{2} \mathrm{X}_{2} \mathrm{R}$ subunit in the rat perifornical hypothalamus and demonstrate that hypothalamic orexin neurons express the $P 2 \mathrm{X}_{2} \mathrm{R}$. Double immunohistochemistry showed that virtually all orexin-immunoreactive neurons are also $\mathrm{P} 2 \mathrm{X}_{2} \mathrm{R}$ immunoreactive, whereas $80 \%$ of $\mathrm{P} 2 \mathrm{X}_{2} \mathrm{R}$-immunoreactive neurons are also orexin positive. Triple-labeling experiments, combining fluorescence in situ hybridization for $\mathrm{P} 2 \mathrm{X}_{2} \mathrm{R}$ mRNA and $\mathrm{P} 2 \mathrm{X}_{2} \mathrm{R}$ /orexin double immunofluorescence, confirmed these findings. In addition, in situ hybridization demonstrated that $\mathrm{P} 2 \mathrm{X}_{2} \mathrm{R}$ mRNA is localized in cellular processes of orexinergic neurons. The present data support neurophysiologic findings on ATP modulation of orexinergic function and provide direct evidence that the entire population of orexin neurons expresses a P2XR subtype, namely, $\mathrm{P} 2 \mathrm{X}_{2} \mathrm{R}$. Thus, purinergic transmission might intervene in modulating key functions known to be controlled by the orexinergic system, such as feeding behavior and arousal. J. Comp. Neurol. 498:58-67, 2006. ๑ 2006 Wiley-Liss, Inc.
\end{abstract}

Indexing terms: perifornical hypothalamus; autonomic regulation; sleep-wake cycle; eating disorders; ATP receptors; mRNA localization

Orexin, also known as hypocretin, is a recently identified neuropeptide that is attracting attention for its role in the regulation of functions associated with arousal and wakefulness (Saper et al., 2001; Mileykovskiy et al., 2005). These include control of the level of alertness, locomotor activity, and appetite; control of metabolism and energy expenditure; control of the neuroendocrine and autonomic nervous systems; modulation of incoming pain signals; and drug-seeking behavior (Sutcliffe and de Lecea, 2002; Ferguson and Samson, 2003; Sakurai, 2003; Mochizuki and Scammell, 2003; Burdakov, 2004; Scammell and Saper, 2005; Harris et al., 2005). Remarkably, orexin originates from a small group of neurons located in restricted parts of the hypothalamus: the perifornical area (PeF), dorsomedial hypothalamus (DMH), and lateral hypothal- amus (LH). These neurons project to many parts of the CNS, from neocortex to spinal cord, and in many respects their targets are consistent with the known functions of orexin. Less is known, however, about what controls these

Grant sponsor: Ministero dell'Istruzione dell'Università e della Ricerca Grant sponsor: Italian Ministry of Health; Grant sponsor: National Heart Foundation of Australia.

*Correspondence to: Marco Molinari, Experimental Neurorehabilitation Lab, I.R.C.C.S. Santa Lucia Foundation, Via Ardeatina 306, 00179 Rome, Italy. E-mail: m.molinari@hsantalucia.it

Received 2 November 2005; Revised 8 February 2006; Accepted 15 March 2006

DOI 10.1002/cne.21013

Published online in Wiley InterScience (www.interscience.wiley.com). 
neurons and which receptors they harbor on their dendrites and soma.

ATP-gated purinergic receptor channels are made up by seven known subunits $\left(\mathrm{P}_{2} \mathrm{X}_{1-7} \mathrm{R}\right)$. They are cationselective channels mediating excitatory synaptic transmission (within milliseconds) and presenting low affinity, in the micromolar range, for ATP. These receptors present almost equal permeability to $\mathrm{Na}^{+}$and $\mathrm{K}^{+}$and substantial calcium permeability (Khakh, 2001; Khakh et al., 2001). P2XR-generated calcium signals, rather than current profiles, mediate the action of these receptors in cellular physiology in many tissues where they are involved in different functions. In the CNS, P2XR are involved in plasticity (Robertson et al., 2001; Florenzano et al., 2006) and neuronal damage (Florenzano et al., 2002; Viscomi et al., 2004) and have been proposed as therapeutic targets in several CNS illnesses (Koles et al., 2005). The $\mathrm{P}_{2} \mathrm{X}_{2} \mathrm{R}$ is diffusely present in the brain and expressed in central autonomic areas of the brainstem and hypothalamus (Vulchanova et al., 1996; Xiang et al., 1998).

Various reports have demonstrated physiological interactions between orexinergic and purinergic systems. The A1 receptors for adenosine, which have been proposed as an endogenous sleep factor, are expressed in orexinergic neurons (Thakkar et al., 2002). Furthermore, it has recently been shown that ATP administration on hypothalamic slices induces a dose-dependent increase in spike frequency of orexin neurons (Wollmann et al., 2005) and DMH neurons (Matsumoto et al., 2004). Thus, physiological and anatomical data suggest the presence of purinergic receptors on orexinergic neurons. In a preliminary report from our group (Florenzano et al., 2003), we showed the presence of the $\mathrm{P}_{2} \mathrm{X}_{2} \mathrm{R}$ in the $\mathrm{PeF}$ where orexin neurons are located. The aim of the present study was therefore to determine whether orexin neurons indeed express the $\mathrm{P} 2 \mathrm{X}_{2} \mathrm{R}$. We performed immunohistochemistry and in situ hybridization to assess the presence of orexin and $\mathrm{P}_{2} \mathrm{X}_{2} \mathrm{R}$ subunit in the same hypothalamic neurons. Confocal microscopy of multiply labeled sections demonstrated that all neurons expressing orexin also express the $\mathrm{P}_{2} \mathrm{X}_{2} \mathrm{R} \mathrm{mRNA}$ and protein. These data validate the previous hypothesis on the role of ATP in controlling orexinergic activity through a $\mathrm{P} 2 \mathrm{XR}$ that contains the $\mathrm{P} 2 \mathrm{X}_{2} \mathrm{R}$ subunit.

\section{MATERIALS AND METHODS}

Nine adult male rats (Wistar; Harlan Italy) weighing 200-250 g were used in this study. They were group housed in standard cages and kept under a 12-hour lightdark cycle in an air-conditioned facility. All experiments were carried out in accordance with the Italian law on the use and care of laboratory animals (DL 116/92). All animals were transcardially perfused under deep anesthesia (Nembutal, $60 \mathrm{mg} / \mathrm{kg}$, i.p.) with $150 \mathrm{ml}$ of $0.9 \%$ saline at room temperature (RT), followed by $200 \mathrm{ml}$ of cold $4 \%$ paraformaldehyde in $0.1 \mathrm{M} \mathrm{pH} 7.4$ phosphate buffer (PB). Brains were dissected, postfixed for 2 hours at room temperature, and cryoprotected in $30 \%$ sucrose/PB at $4^{\circ} \mathrm{C}$. They were then frozen with dry ice and cut into $40-\mu \mathrm{m}$ transverse sections with a sliding microtome. Different series of transverse sections through the diencephalon were collected in $\mathrm{PB}$ and stored at $4^{\circ} \mathrm{C}$. These series were used for cresyl violet staining, immunoperoxidase staining, and blocking tests (three rats); single and double immunofluorescence (three rats); in situ hybridization; and combined in situ hybridization and double immunofluorescence (three rats). For animals destined for in situ hybridization and for multiple labeling combining in situ and immunofluorescence perfusion saline and PB solutions were treated with diethyl pyrocarbonate (DPEC) in all steps until hybridization.

\section{Immunohistochemistry}

Primary antibodies and procedures. In the present study, the following primary antibodies were used: 1) a polyclonal rabbit anti-P $2 \mathrm{X}_{2} \mathrm{R}$ raised against an intracellular C-terminal epitope (residues 457-472; product No. 003; Alomone, Jerusalem, Israel); this antibody was used for all the immunoistochemical procedures; 2) a polyclonal guinea pig anti-P2X $\mathrm{X}_{2} \mathrm{R}$ raised against an intracellular C-terminal epitope (residues 460-472; catalog No. GP14106; Neuromics, Minneapolis, MN); this antibody was used only as control in single label immunoperoxidase staining; and 3) a polyclonal goat antiorexin-A antibody raised against a peptide mapping at the carboxy terminus (residues 30-80, catalog sc-8070, C-19; Santa Cruz Biotechnology, Santa Cruz, CA). Immunohistochemical procedures as well as immunoperoxidase and double- and triple-labeling fluorescent techniques were performed at $\mathrm{RT}$ on free-floating sections. PB/Triton-X $0.3 \%$ was used for both antibody dilutions and washes, and every incubation was followed by three washes of 5 minutes each.

Immunoperoxidase staining. For single-labeling immunoperoxidase, sections were treated for 5 minutes with $0.3 \% \mathrm{H}_{2} \mathrm{O}_{2}$ to block endogenous peroxidase and incubated overnight in rabbit anti-P2X $\mathrm{X}_{2} \mathrm{R}$ (1:500; Alomone), or guinea pig anti-P2X $\mathrm{X}_{2} \mathrm{R}$ (1:500; Neuromics), or goat antiorexin-A (1:20,000). After incubation with the primary antiserum, sections were incubated for 2 hours in the respective biotinylated secondary antiserum (1:200, donkey anti-rabbit, goat anti-guinea pig, or horse anti-goat; Jackson Immunoresearch, West Grove, PA). Then, sections were incubated for 1 hour in avidin-biotin complex (1:100; Vectastain Elite; Vector Laboratories, Burlingame, CA). For visualization, the chromogen 3,3'diaminobenzidine (DAB; $0.05 \%$ ) with nickel intensification was used. Finally, sections were mounted on chromealum-coated slides, air dried, dehydrated with ethanol, cleared in xylene, and coverslipped.

Blocking tests. The specificity of the primary antisera was verified by preabsorption with their own specific target peptides in single-labeling immunoperoxidase-stained sections. In addition, to exclude the possibility of a crossreaction between the $P 2 X_{2} R$ antiserum and the orexin protein and between the orexin antiserum and the $P 2 \mathrm{X}_{2} \mathrm{R}$ protein, preabsorptions were also done between the $\mathrm{P}_{2} \mathrm{X}_{2} \mathrm{R}$ antiserum (Alomone) and the orexin peptide (Bachem, Bubendorf, Switzerland) and between the orexin antiserum and the $\mathrm{P}_{2} \mathrm{X}_{2} \mathrm{R}$ peptide (Alomone). The preabsorptions were done by mixing the antisera, at the same concentrations as above, with the peptides $(30 \mu \mathrm{g} / \mathrm{ml}$ for orexin and $50 \mu \mathrm{g} / \mathrm{ml}$ for $\mathrm{P}_{2} \mathrm{X}_{2} \mathrm{R}$ peptides) for 1 hour before to incubate the sections. The specificity of the $\mathrm{P}_{2} \mathrm{X}_{2} \mathrm{R}$ distribution pattern was verified by comparing sections in single-labeling immunoperoxidase reacted with $\mathrm{P} 2 \mathrm{X}_{2} \mathrm{R}$ antibodies from Alomone and Neuromics.

Double labeling. Double immunofluorescence was performed with a cocktail solution of goat antiorexin antibody (1:400) and rabbit anti-P2X 2 R antibody (1:100; 
Alomone). After overnight incubation, the sections were incubated for 2 hours in a cocktail of Cy2-conjugated donkey anti-goat and Cy3-conjugated donkey anti-rabbit IgG secondary antibodies (1:100; Jackson Immunoresearch). Sections were then mounted on gelatin-coated slides and coverslipped in Gel Mount (Biomeda, Foster City, CA).

\section{In situ hybridization}

A fragment of the rat purinergic $P 2 X_{2} R$ mRNA was amplified by polymerase chain reaction (PCR). The forward primer (nt 1,461-1,480; 5'-TCCTCACTAAACTACAGACC$\left.3^{\prime}\right)$ and the reverse primer (nt 1,721-1,740; 5' CCCTGAATACTGTATGAGAG-3') were designed to amplify a fragment of the $3^{\prime} \mathrm{UTR}$ of the $\mathrm{P} 2 \mathrm{X}_{2} \mathrm{R}$ mRNA (accession No. NM_053656). The 279-bp product was gel purified and cloned into the pGEM-T-EasyVector System I (Promega, Madison, WI) and sequenced. The construct was linearized with SacI or SacII to synthesize the digoxigenin-labeled sense or antisense probes with the SP6 or T7 RNA polymerase, respectively. Transcriptions were performed with the in vitro MAXIscript kit (Ambion, Austin, TX).

In situ hybridization with the digoxigenin-UTP probes was performed in free-floating permeabilized sections. The sections were incubated with Sigma prehybridization buffer (30 minutes), then hybridized overnight at $56^{\circ} \mathrm{C}$ in hybridization buffer (Sigma, St. Louis, MO) containing $500 \mathrm{ng}$ of the denaturated antisense or sense probes. After the hybridization, the sections were washed in $2 \times \mathrm{SSC}$ buffer, RNase-treated $(10 \mu \mathrm{g} / \mathrm{ml})$ for 30 minutes at $37^{\circ} \mathrm{C}$, and washed twice in $0.5 \times \mathrm{SSC}$ buffer at $56^{\circ} \mathrm{C}$ for 30 minutes. The probe was then visualized by immunofluorescence by a TRITC-conjugated sheep antidigoxigenin antibody (1:100; Roche, Mannheim, Germany). The same procedure was performed with sense probes that failed to give any signals.

Triple labeling was carried out by first incubating the sections labeled for $\mathrm{P} 2 \mathrm{X}_{2} \mathrm{R}-\mathrm{mRNA}$ with a cocktail solution of the primary antibodies antiorexin (1:400) and anti$\mathrm{P}_{2} \mathrm{X}_{2} \mathrm{R}$ (1:100; Alomone). After overnight incubation, sections were incubated for 2 hours in a cocktail of Cy5conjugated donkey anti-goat, Cy2-conjugated donkey antirabbit IgG secondary antibodies (1:100; Jackson Immunoresearch) and TRITC-conjugated sheep antidigoxigenin antibody (1:100; Roche). Sections were mounted on gelatin-coated slides and coverslipped in Gel Mount.

\section{Qualitative and quantitative analysis}

The immunoperoxidase material was examined with a light transmission microscope (Zeiss Axioskop 2) equipped with a video camera. Double-immunofluorescence and triple-fluorescence labeling was examined with a confocal laser scanning microscope (CLSM; Zeiss LSM 510) equipped with an argon laser emitting at $488 \mathrm{~nm}$, a helium/neon laser emitting at $543 \mathrm{~nm}$, and a helium/neon laser emitting at $633 \mathrm{~nm}$. In some acquisitions, to give evidence of axons and dendrites located on focal planes far from the cell bodies, we generated projections from a z-stack series of images acquisition of optical sections at increments of $1.04 \mu \mathrm{m}$ in the z-axis, $\times 100$ magnification, 0.7 scan zoom, and digitized at $1,024 \times 1,024$ pixels.

The quantitative analysis of single, double, and triple immunofluorescence-labeled neurons was performed on digital images acquired through CLSM by using a $\times 10$ objective at a 0.7 zoom factor. Qualitative and quantita- tive observations were limited to the caudal half of the hypothalamus (2 to $4 \mathrm{~mm}$ behind Bregma) in particular focusing on PeF, LH, and DMH areas (Paxinos and Watson, 1994; Paxinos, 2004). Labeled cells were identified based on the cellular profile.

Three animals were used for of $\mathrm{P} 2 \mathrm{X}_{2} \mathrm{R} /$ orexin doublelabeling quantitative analyses. For each animal, all labeled cells in 10 sections were counted. Quantitative analyses in triple-labeled material was performed in three animals by counting all labeled cells in two sections. Double- and triple-labeled neurons were analyzed off-line through a CLSM proprietary image analysis program (Zeiss, LSM 2.3). Two or three digital images of the same optical section (one for each laser channel: green, red, and blue) were acquired, digitally merged, and used for cell counting. The features of immunolabeled neurons were analyzed by zooming on the cells and by serially excluding each channel (green, red, or blue) better to appreciate cellular labeling. Morphometric measures were obtained by using the image-analysis tools in the CLSM proprietary image-analysis program (Zeiss LSM 2.3). Plates were generated with adjustment of the contrast and brightness of digital images (Corel Draw 9).

\section{RESULTS}

$\mathrm{P} 2 \mathrm{X}_{2} \mathrm{R}$ immunostaining of the diencephalon with anti$\mathrm{P}_{2} \mathrm{X}_{2} \mathrm{R}$ rabbit polyclonal antibodies resulted in the labeling of cell bodies and fibers in restricted regions. In general, the $\mathrm{P}_{2} \mathrm{X}_{2} \mathrm{R}$ pattern observed was similar to that previously described, with labeled cells in the paraventricular, arcuate, tuberomammilary, and supraoptic nuclei (Vulchanova et al., 1996; Xiang et al., 1998; Yao et al., 2003). In addition, in our material, a conspicuous group of $\mathrm{P}_{2} \mathrm{X}_{2} \mathrm{R}$-positive neurons was observed in the dorsal part of the tuberal hypothalamus, centered on the PeF, immediately above the fornix (Fig. 1A). Labeled cells extended laterally into the $\mathrm{LH}$ and medially into the $\mathrm{DMH}$. In the $\mathrm{DMH}$, fewer neurons were stained compared with the $\mathrm{PeF}$. In the material reacted with the anti-P2X $\mathrm{X}_{2} \mathrm{R}$ antibody raised in guinea pig from Neuromics, although the general pattern of hypothalamic staining was similar to that previously reported (Vulchanova et al., 1996; Xiang et al., 1998; Yao et al., 2003), positive neurons were not present in PeF, LH, or DMH areas (data not shown).

To verify the specificity of the $\mathrm{P} 2 \mathrm{X}_{2} \mathrm{R}$ rabbit antibodies, as well of the orexin antibodies, we performed several blocking tests. No blocking tests for the guinea pig $\mathrm{P}_{2} \mathrm{X}_{2} \mathrm{R}$ antibodies were performed. Preabsortion with the $\mathrm{P} 2 \mathrm{X}_{2} \mathrm{R}$ peptide completely abolished all staining (Fig. 1E). The specificity of the $\mathrm{P} 2 \mathrm{X}_{2} \mathrm{R}$ signal at the protein level was further investigated by performing an mRNA in situ hybridization for the $\mathrm{P} 2 \mathrm{X}_{2} \mathrm{R}$ receptor (Fig. 2A). Also in this case, $P 2 X_{2} R$ mRNA was found in restricted regions of the hypothalamus, but, most importantly, it was also present in $\mathrm{PeF}, \mathrm{LH}$, and $\mathrm{DMH}$, areas where $\mathrm{P}_{2} \mathrm{X}_{2} \mathrm{R}$-positive neurons were revealed by immunohistochemistry. As shown in Figure 2A, the P2X ${ }_{2} \mathrm{R}$ mRNA signal was not limited to the cell bodies but was also high in fibers and possibly in terminals. The $\mathrm{P} 2 \mathrm{X}_{2} \mathrm{R}$ mRNA signal was almost absent when the sense P2X ${ }_{2} R$ mRNA probe was used (Fig. 2D).

In sections reacted with antiorexin antibody, orexinpositive neurons were also found in the hypothalamus centered on the PeF and extending into the LH laterally and the DMH medially. The distribution of orexin neurons 

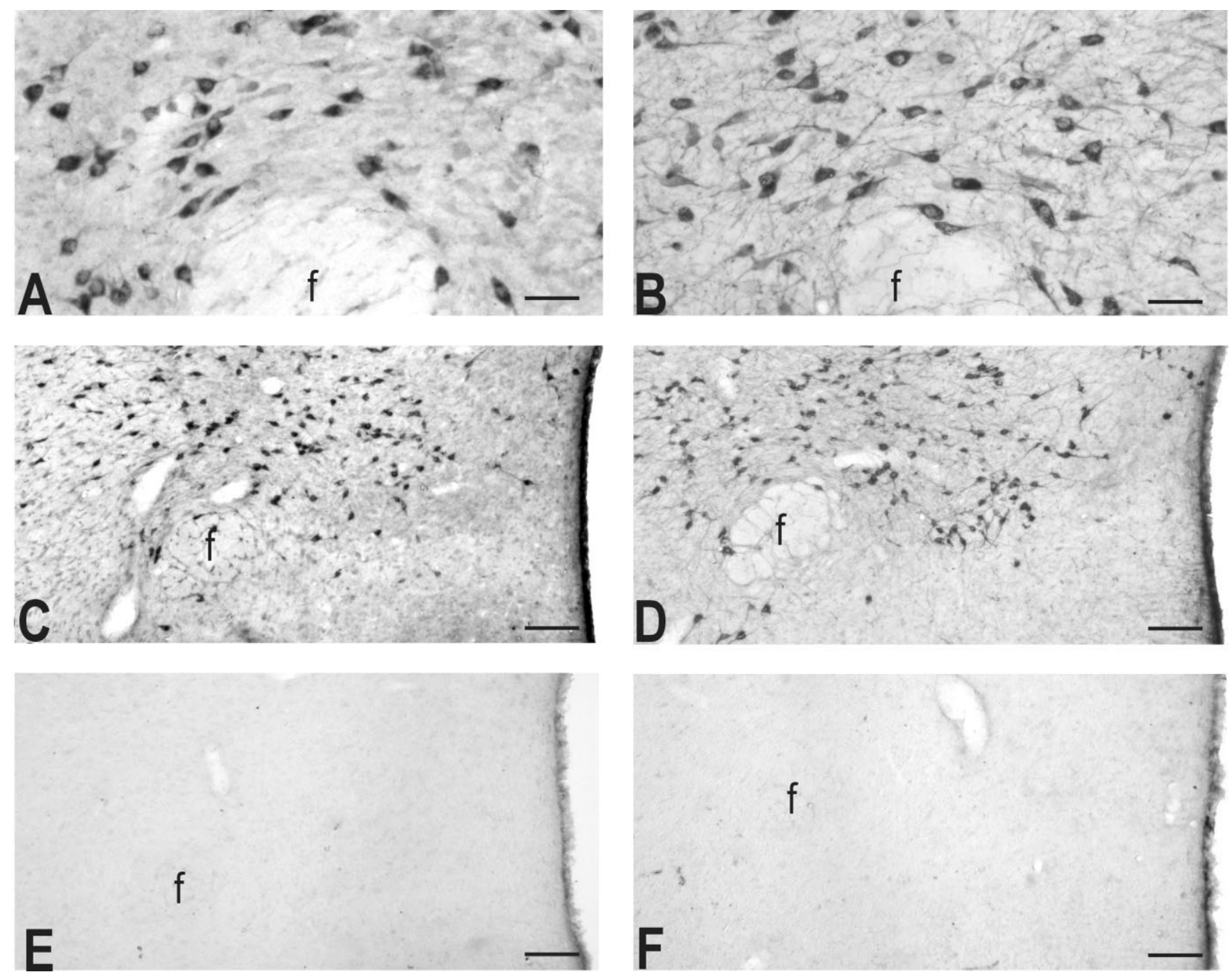

Fig. 1. Immunoperoxidase staining of hypothalamic sections through the perfornical area reacted for the P2X $\mathrm{X}_{2} \mathrm{R}$ subunit $(\mathbf{A}, \mathbf{C}, \mathbf{E})$ or orexin $(\mathbf{B}, \mathbf{D}, \mathbf{F})$. C-F: Blocking tests. In $\mathrm{C}$ and $\mathrm{F}$, sections preabsorbed with the orexin peptide, and, in $\mathrm{D}$ and $\mathrm{E}$, sections preabsorbed with the $\mathrm{P} 2 \mathrm{X}_{2} \mathrm{R}$ peptide. f, Fornix. Scale bars $=$ $60 \mu \mathrm{m}$ in $\mathrm{A}, \mathrm{B} ; 400 \mu \mathrm{m}$ in $\mathrm{C}-\mathrm{F}$.

in $\mathrm{PeF}, \mathrm{LH}$, and $\mathrm{DMH}$ presented a striking similarity to that of the $\mathrm{P} 2 \mathrm{X}_{2} \mathrm{R}$-labeled cells, suggesting that the two proteins could be expressed by the same cells. This can be appreciated by comparing sections immunostained for orexin or for $\mathrm{P} 2 \mathrm{X}_{2} \mathrm{R}$ (Fig. 1).

The suggestion that the two proteins might be colocalized in the same neuronal population was then tested by double immunofluorescence for $\mathrm{P}_{2} \mathrm{X}_{2} \mathrm{R}$ and orexin and by coupling this double immunofluorescence with in situ hybridization fluorescence for mRNA P2X 2 . Confocal microscopy of double immunofluorescence for orexin and $\mathrm{P}_{2} \mathrm{X}_{2} \mathrm{R}$ showed a very high degree of colocalization in cell bodies and varicose processes (Fig. 2G-I). Indeed, almost all orexin-positive cells were also $\mathrm{P} 2 \mathrm{X}_{2} \mathrm{R}$ positive, with only a small population of $\mathrm{P}_{2} \mathrm{X}_{2} \mathrm{R}$-positive cells not expressing orexin. This small population of $\mathrm{P}_{2} \mathrm{X}_{2} \mathrm{R}$-positive/ orexin-negative cells was evenly distributed and intermingled with the population of double-labeled cells (Fig. 2I). Quantitative analyses performed on $\mathrm{PeF}, \mathrm{DMH}$, and $\mathrm{LH}$ areas are reported in Table 1 and confirmed the qualitative observations; i.e., virtually all orexin-positive cells were $\mathrm{P}_{2} \mathrm{X}_{2} \mathrm{R}$ positive, whereas between $75 \%$ and $80 \%$ of $\mathrm{P} 2 \mathrm{X}_{2} \mathrm{R}$-positive cells were orexin positive.

The possibility of cross-reactivity between the antisera and the orexin or $\mathrm{P} 2 \mathrm{X}_{2} \mathrm{R}$ epitopes was ruled out by blocking tests. Preabsorption of each antisera with the two peptides was performed before running the immunohistochemical reaction. $\mathrm{P} 2 \mathrm{X}_{2} \mathrm{R}$ immunoreactivity was not reduced by preabsorption with the orexin peptide (Fig. 1C), although it was absent after preabsorption with the $\mathrm{P}_{2} \mathrm{X}_{2} \mathrm{R}$ peptide (Fig. 1E). Similarly, orexin immunoreactivity was not reduced by preabsorption with the $\mathrm{P}_{2} \mathrm{X}_{2} \mathrm{R}$ peptide (Fig. 1D) but was absent after preabsorption with the orexin peptide (Fig. 1F). The capacity of orexin neurons to express $\mathrm{P} 2 \mathrm{X}_{2} \mathrm{R}$ was further tested by coupling double immunofluorescence for $\mathrm{P} 2 \mathrm{X}_{2} \mathrm{R}$ and orexin with in situ hybridization fluorescence for $\mathrm{P}_{2} \mathrm{X}$ mRNA. As expected, in the examined areas, almost all orexin-positive 

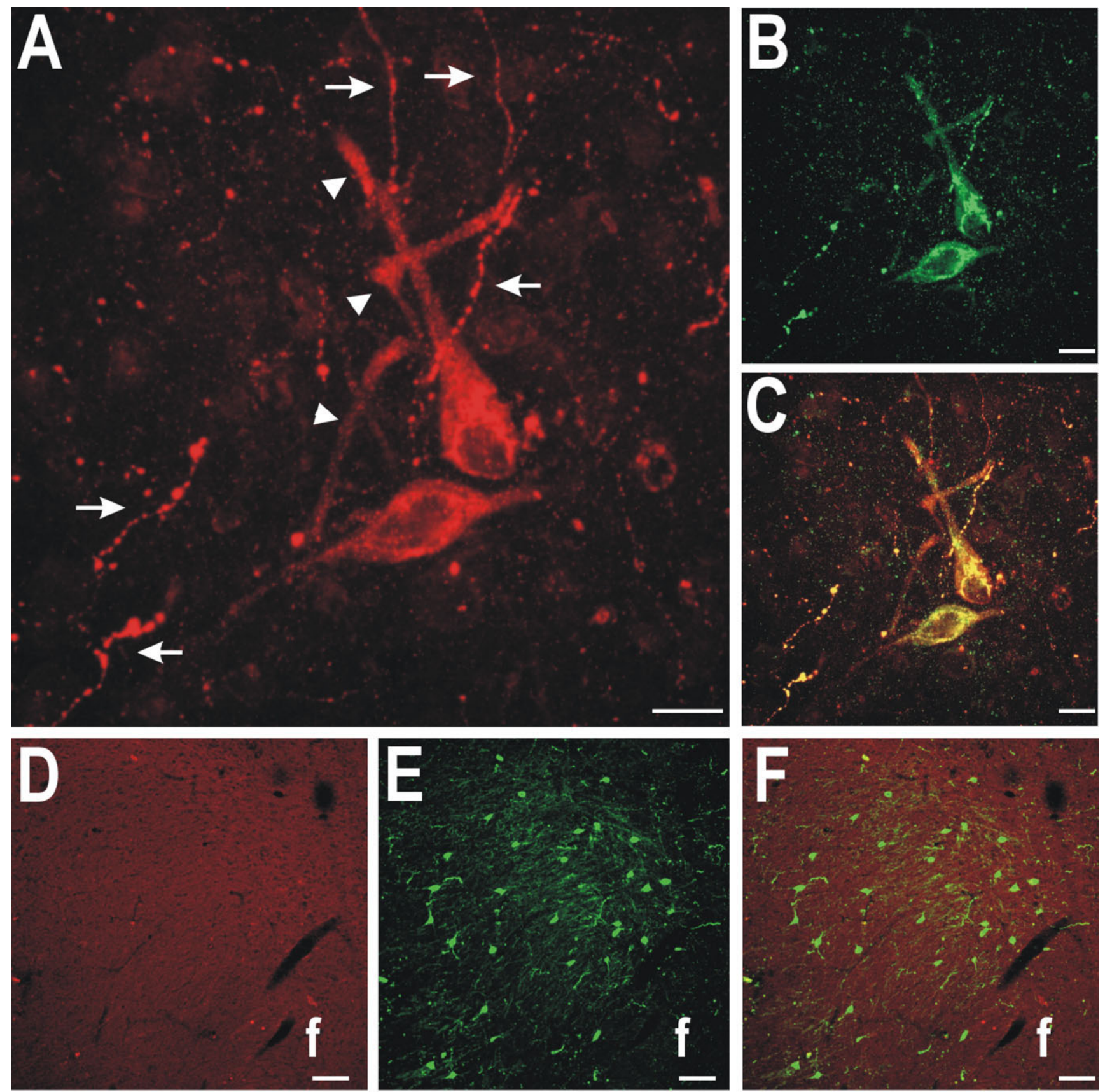

D
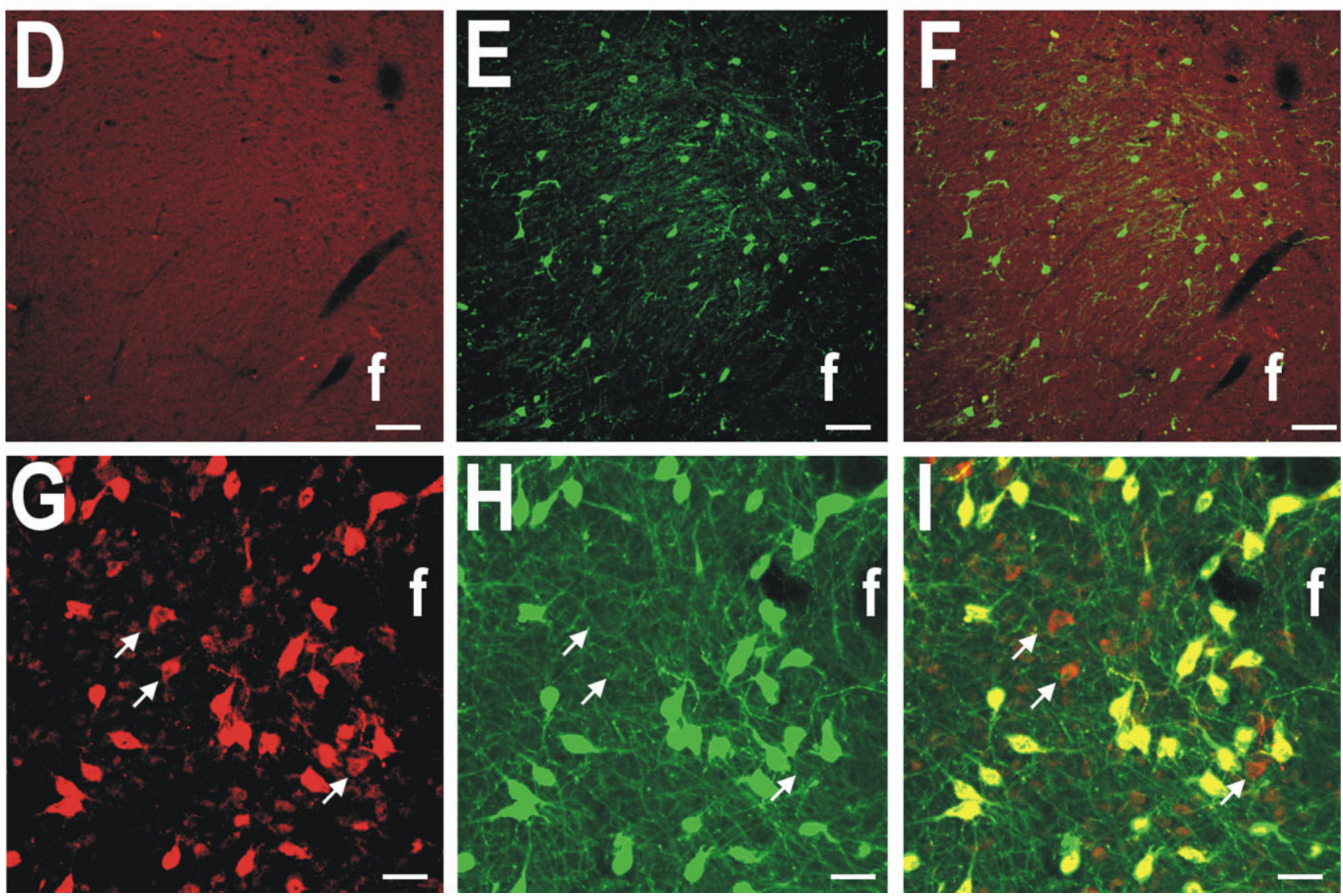
TABLE 1A. Double Labelling: Number of Cells in 10 Sections Throughout the PeF, DMH, and LH Areas

\begin{tabular}{|c|c|c|c|c|c|c|c|}
\hline & Total cells & Prot & Orx & Prot/Orx & $\begin{array}{c}\text { Percentage DL } \\
\text { on total cells }\end{array}$ & $\begin{array}{l}\text { Percentage } \\
\text { DL on Orx }\end{array}$ & $\begin{array}{l}\text { Percentage } \\
\text { DL on Prot }\end{array}$ \\
\hline Rat 1 & 474 & 88 & 18 & 368 & 77.64 & 95.34 & 80.70 \\
\hline Rat 2 & 466 & 108 & 9 & 349 & 74.89 & 97.49 & 76.37 \\
\hline Rat 3 & 455 & 110 & 13 & 332 & 72.97 & 96.23 & 75.11 \\
\hline Mean & 465.00 & 102.00 & 13.33 & 349.67 & 75.17 & 96.35 & 77.39 \\
\hline SD & 9.54 & 12.17 & 4.51 & 18.01 & 2.35 & 1.08 & 2.93 \\
\hline
\end{tabular}

${ }^{1}$ Prot, $\mathrm{P} 2 \mathrm{X}_{2} \mathrm{R}$ protein; RNA, P2X 2 R mNA; Orx, orexin protein.

TABLE 1B. Triple Labelling: Number of Cells in Two Sections Throughout the PeF, DMH, and LH Areas

\begin{tabular}{|c|c|c|c|c|c|c|c|c|c|}
\hline & \multirow[b]{2}{*}{$\begin{array}{c}\text { Total } \\
\text { cells }\end{array}$} & \multicolumn{3}{|c|}{ Single labelling } & \multicolumn{3}{|c|}{ Double labelling } & \multicolumn{2}{|c|}{ Triple labelling } \\
\hline & & Prot & RNA & Orx & Prot/RNA & Prot/Orx & RNA/Orx & Prot/RNA/Orx & $\begin{array}{c}\text { Percentage } \\
\text { Prot/RNA/Orx }\end{array}$ \\
\hline Rat 1 & 60 & 2 & 2 & 0 & 2 & 4 & 1 & 49 & 81.67 \\
\hline Rat 2 & 109 & 3 & 1 & 0 & 1 & 3 & 1 & 100 & 91.74 \\
\hline Rat 3 & 108 & 3 & 0 & 0 & 2 & 1 & 1 & 101 & 93.52 \\
\hline Mean & 92.33 & 2.67 & 1.00 & 0.00 & 1.67 & 2.67 & 1.00 & 83.33 & 88.98 \\
\hline SD & 28.01 & 0.58 & 1.00 & 0.00 & 0.58 & 1.53 & 0.00 & 29.74 & 6.39 \\
\hline
\end{tabular}

${ }^{1}$ Prot, $\mathrm{P} 2 \mathrm{X}_{2} \mathrm{R}$ protein; RNA, P2X $\mathrm{X}_{2} \mathrm{mRNA}$; Orx, orexin protein.

cells were found to express both the $\mathrm{P} 2 \mathrm{X}_{2} \mathrm{R}$ protein and the P2X 2 R mRNA (Table 1, Figs. 3, 4).

The intracellular distribution of $\mathrm{P}_{2} \mathrm{X}_{2} \mathrm{R}$ protein and mRNA signals presented some peculiar aspects. Immunoperoxidase staining showed $\mathrm{P} 2 \mathrm{X}_{2} \mathrm{R}$ protein expression to be moderate to intense, with an uneven labeling of the soma and proximal processes but not of the nucleus (Fig. 5 ). The $P 2 X_{2} R$ protein pattern of expression presented a gross granular appearance in discrete cytoplasmic regions, especially on the major cellular axis around the nucleus. In confocal images of multiply labeled sections (Figs. 2A-C, 5B-G), the granules were positive for both $\mathrm{P}_{2} \mathrm{X}_{2} \mathrm{R}$ protein and mRNA, suggesting a colocalization in the same intracellular structures. In the outer part of the cytoplasm as well in dendrites, the granularity appeared more delicate, possibly indicating a vesicular storage. In the neuropil, varicose processes, resembling axonal structures, presented high positivity for orexin, $\mathrm{P} 2 \mathrm{X}_{2} \mathrm{R}$ protein, and $\mathrm{P} 2 \mathrm{X}_{2} \mathrm{R}$ mRNA (Fig. 5E-G). The staining appeared grossly granular. Morphometric analysis showed that the size of positive varicosities ranged between 0.5 and 2.0 $\mu \mathrm{m}$, considerably larger that the granules observed in the outer part of the soma and proximal dendrites, which ranged between 0.2 and $0.5 \mu \mathrm{m}$.

\section{DISCUSSION}

The present data demonstrate that $\mathrm{P} 2 \mathrm{X}_{2} \mathrm{R}$ are present in virtually all orexin neurons of $\mathrm{PeF}, \mathrm{LH}$, and $\mathrm{DMH}$ areas

Fig. 2. Confocal images through PeF and LH areas. A-C: In situ $\mathrm{P}_{2} \mathrm{X}_{2} \mathrm{R}$ mRNA hybridization with the antisense oligonucleotide coupled with $\mathrm{P}_{2} \mathrm{X}_{2}$ protein immunofluorescence. Projection of 14 confocal images. A: $P 2 X_{2} R$ mRNA. B: $P 2 X_{2} R$ protein. C: Merge. Note the accumulation of $\mathrm{P} 2 \mathrm{X}_{2} \mathrm{R}$ mRNA and $\mathrm{P} 2 \mathrm{X}_{2} \mathrm{R}$ protein in dendrites (arrowheads), fibers, and varicosities (arrows). D-F: In situ $\mathrm{P}_{2} \mathrm{X}_{2} \mathrm{R}$ mRNA hybridization with the sense oligonucleotide coupled with orexin immunofluorescence. D: P2X ${ }_{2} R$ mRNA. E: Orexin. F: Merge. G-I: Double immunofluorescence for $P 2 X_{2} R$ protein and orexin. $G$ $\mathrm{P}_{2} \mathrm{X}_{2} \mathrm{R}$ protein. H: Orexin. I: Merge. Note that some $\mathrm{P} 2 \mathrm{X}_{2} \mathrm{R}$ labeled cells do not stain for orexin (arrows). f, Fornix. Scale bars $=10 \mu \mathrm{m}$ in $\mathrm{A}-\mathrm{C} ; 50 \mu \mathrm{m}$ in $\mathrm{D}-\mathrm{F} ; 30 \mu \mathrm{m}$ in $\mathrm{G}-\mathrm{I}$. of the dorsal tuberal hypothalamus, providing anatomical evidence to support the hypothesized ATP modulation of orexin neurons through $\mathrm{P}_{2} \mathrm{X}_{2} \mathrm{R}$. The presence of purinergic receptors on orexin neurons is in line with other observations. About $30 \%$ of orexin neurons express the adenosine receptor $\mathrm{A} 1$, a purinergic receptor (P1), and a key regulator in the control of sleep-wakefullness (Thakkar et al., 2002). P2XR have also been implicated in thermoregulation (Gurin et al., 2003), as have orexin neurons (Monda et al., 2003). Possibly the most compelling evidence derives from electrophysiological experiments on $\mathrm{LH}$ and DMH orexin neurons, which show 1) that ATP application can increase orexin cell activity in a dosedependent manner independently of synaptic input, suggestive of postsynaptic ion channel opening (Matsumoto et al., 2004; Wollmann et al., 2005), and 2) P2XR-dependent responses, consistent with the presence of $\mathrm{P} 2 \mathrm{X}_{2} \mathrm{R}$ (Jo and Role, 2002; Matsumoto et al., 2004; Wollmann et al., 2005).

Previous studies addressed the distribution of purinergic receptors in the hypothalamus by immunohistochemistry and failed to reveal $\mathrm{P} 2 \mathrm{X}_{2} \mathrm{R}$-positive neurons in the dorsal tuberal hypothalamus (Vulchanova et al., 1996; Xiang et al., 1998; Kanjhan et al., 1999), where orexin neurons are located (Peyron et al., 1998; Nambu et al., 1999). Indeed, antibodies used in previous studies (Vulchanova et al., 1996; Xiang et al., 1998; Yao et al., 2003), such as one of the anti-P2 $\mathrm{X}_{2} \mathrm{R}$ antibodies used in the present study (namely, the guinea pig antibody), did not evidence $\mathrm{P} 2 \mathrm{X}_{2} \mathrm{R}$-positive cells in $\mathrm{PeF}, \mathrm{LH}$, or $\mathrm{DMH}$ areas. This is the first time that $\mathrm{P}_{2} \mathrm{X}_{2} \mathrm{R}$-positive neurons have been identified in these latter areas. A possible explanation for the difference from previous reports resides in the expression of different splice variants of the $\mathrm{P}_{2} \mathrm{X}_{2} \mathrm{R}$ subunit as well as in detection methods (Stojilkovic et al., 2005). Indeed, it has been reported that some of these splice variants present different neuronal distributions at the mRNA level (Simon et al., 1997; Schadlich et al., 2001). The use of a fluorescent riboprobe in the $3^{\prime} \mathrm{UTR}$ region of the mRNA allowed us to recognize all the splice variants. Finally, differences from previous reports in the $\mathrm{P}_{2} \mathrm{X}_{2} \mathrm{R}$ hypothalamic labeling could be due to the specific- 
ity of the antibodies used, as observed in the present study with one of the two $\mathrm{P} 2 \mathrm{X}_{2} \mathrm{R}$ antibodies tested. The preabsorption experiments and in situ hybridization for $P 2 X_{2} R$ mRNA performed support the specificity of the $P 2 X_{2} R$ labeling in orexin neurons.

The possibility that orexin cells may express other P2XR subunits as part of heteromeric P2XR channels appears likely. Nevertheless, preliminary immunohistochemical experiments testing $\mathrm{P}_{2} \mathrm{X}_{1,4,7}$ subtypes in the orexin hypothalamic region have not resulted in significant labeling (data not shown). However, caution is warranted in that, as already observed with the $\mathrm{P} 2 \mathrm{X}_{2} \mathrm{R}$ subtype, immunohistochemistry can provide false-negative results. Heteromeric or homomeric assembly of different P2XR subunits modulates the receptor functionality, and this issue could be of particular interest in understanding
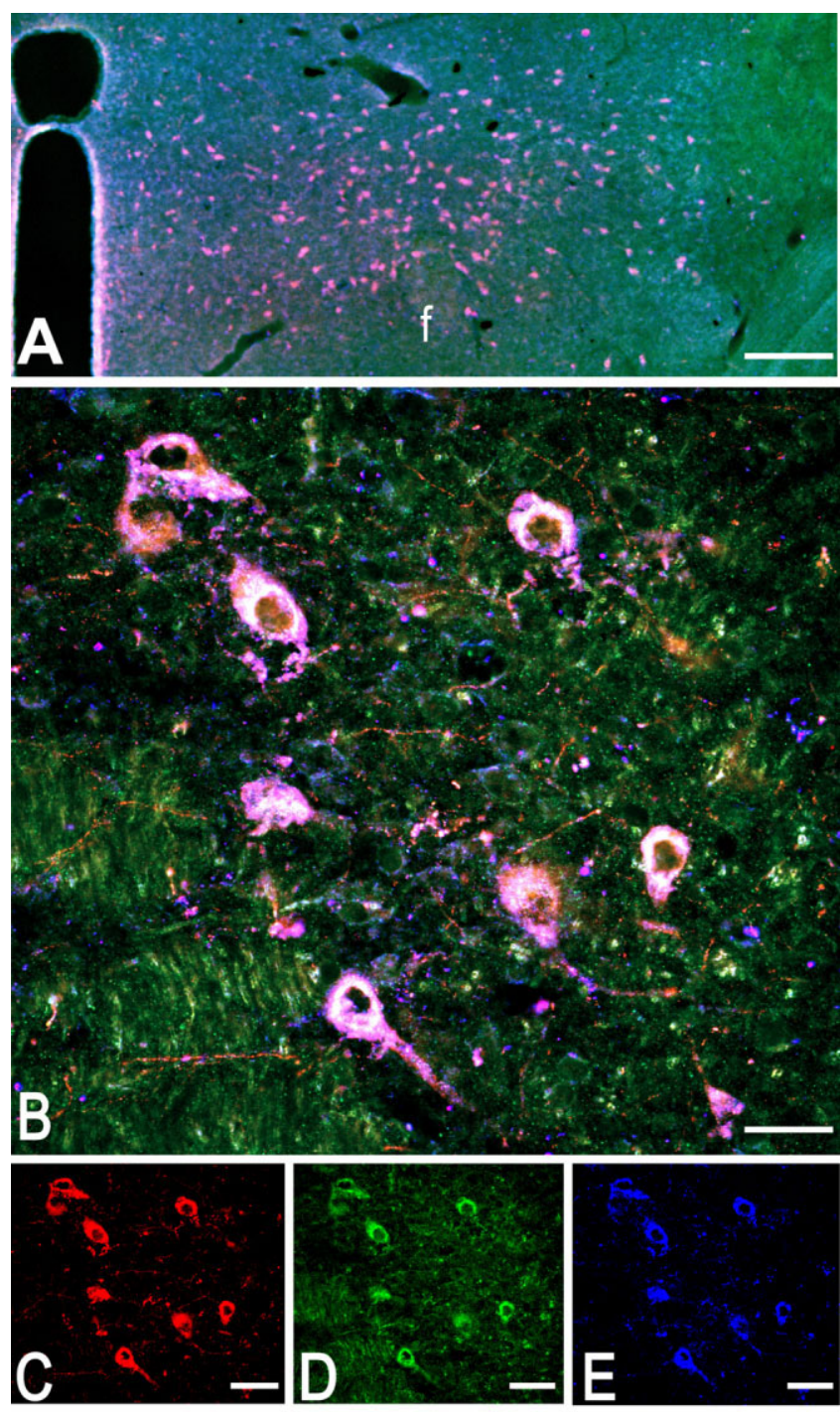

Fig. 3. Confocal images of triple labeling in PeF, DMH, and $\mathrm{LH}$ areas obtained by coupling in situ $\mathrm{P}_{2} \mathrm{X}_{2} \mathrm{R}$ mRNA hybridization and $\mathrm{P} 2 \mathrm{X}_{2} \mathrm{R}$ /orexin double immunohistochemistry. A,B: Merge. C: $\mathrm{P} 2 \mathrm{X}_{2} \mathrm{R}$ mRNA (red). D: $\mathrm{P}_{2} \mathrm{X}_{2} \mathrm{R}$ protein (green). E: Orexin (blue). f, Fornix. Scale bars $=300 \mu \mathrm{m}$ in $\mathrm{A} ; 40 \mu \mathrm{m}$ in $\mathrm{B} ; 10 \mu \mathrm{m}$ in $\mathrm{C}-\mathrm{E}$. the cellular and molecular features that shape the functions of orexinergic neurons. Indeed, these neurons can sustain a fast firing rate (Burdakov, 2004) that does not depend on sodium- or calcium voltage-dependent currents (Eggermann et al., 2003). P2XR are voltage-independent calcium channels, which can sustain a rise in calcium under different conditions from those needed in voltagedependent calcium signaling pathways (Robertson et al., 2001). In fact, the homomeric $P 2 X_{2} R$ presents the highest calcium permeability and longest desensitization time among the various subunits (North, 2002). Thus, the physiological properties of $\mathrm{P}_{2} \mathrm{X}_{2} \mathrm{R}$ are compatible with some interesting aspects of the electrical activity of orexinergic neurons.

The $\mathrm{P}_{2} \mathrm{X}_{2} \mathrm{R}$ protein and mRNA subcellular expression pattern presents some interesting features that could be related to the receptor trafficking and synaptic plasticity. In our material, the $\mathrm{P} 2 \mathrm{X}_{2} \mathrm{R}$ protein and mRNA colocalized in intracellular granules of various sizes located in the soma and cellular processes as well as in distal axonal branches. At the protein level, this subcellular pattern of expression of the receptor seems to reflect mainly the main sites of trafficking, then the final sites of expression, the cellular membrane. A possible explanation is that immunocytochemical methods detect more efficiently the sites presenting a higher antigen concentration, such as the trafficking sites. In support of this hypothesis are light and electron microscopy observations on $\mathrm{P}_{2} \mathrm{X}_{2} \mathrm{R}$ (Loesch et al., 1999) as well as on other ligand-gated receptors, such as glutamate receptors (Petralia and Wenthold, 1992; Petralia et al., 1994; Tachibana et al., 1994). Indeed, earlier investigations performed on AMPA and NMDA receptors (Petralia and Wenthold, 1992; Petralia et al., 1994; Tachibana et al., 1994) have shown that the subcellular distribution pattern reflects mainly the sites of receptor protein synthesis, modification, and transport. For the $\mathrm{P}_{2} \mathrm{X}_{2} \mathrm{R}$, electron microscopy investigations in the hypothalamicneurohypophysial system (Loesch et al., 1999) have shown receptor expression in the cell body primarily associated with the cytoplasm, granular endoplasmic reticulum, mitochondria, and neurosecretory granules. In the same

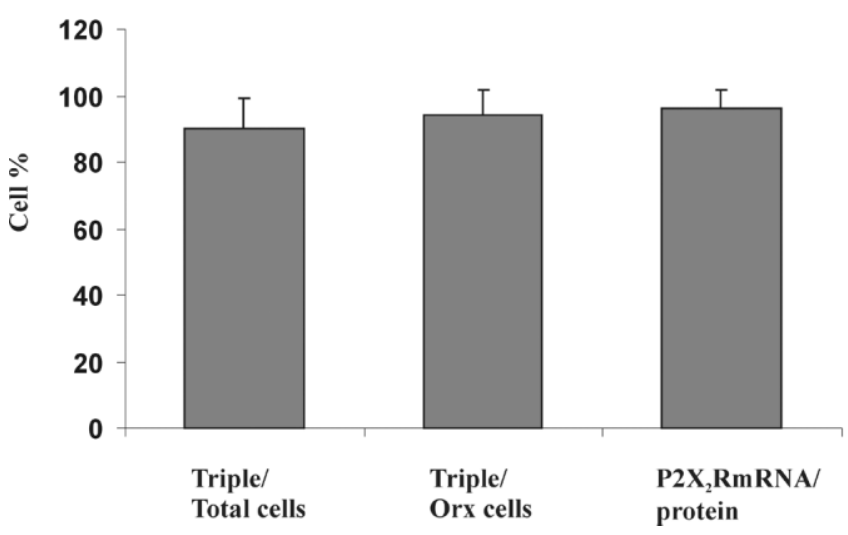

Fig. 4. Histogram of cell counts of orexin and $\mathrm{P} 2 \mathrm{X}_{2} \mathrm{R}$ protein immunofluorescence and mRNA in situ hybridization. Triple/total cells: percentage of triple-labeled cells on the total number of labeled cells. Triple/Orx cells: percentage of orexin neurons expressing also $P 2 X_{2} R$ protein and mRNA. $\mathrm{P} 2 \mathrm{X}_{2} \mathrm{RmRNA} /$ protein: percentage of $\mathrm{P} 2 \mathrm{X}_{2} \mathrm{R}$ protein-positive neurons also positive for $\mathrm{P} 2 \mathrm{X}_{2} \mathrm{R}$ mRNA. 

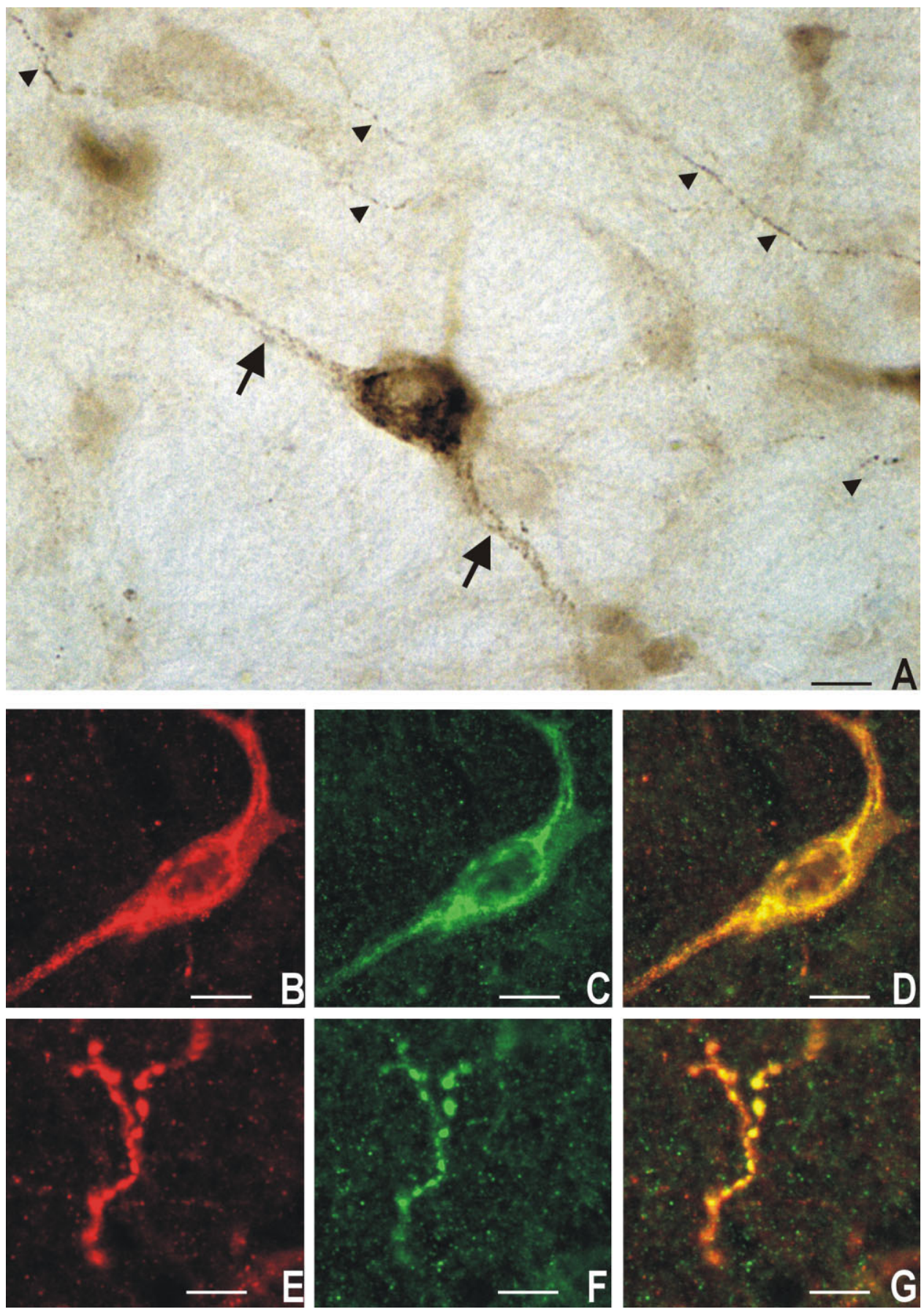

Fig. 5. High magnification of $\mathrm{P} 2 \mathrm{X}_{2} \mathrm{R}$ protein and mRNA labeled cells in the LH. A: Immunoperoxidase single labelling for $\mathrm{P}_{2} \mathrm{X}_{2} \mathrm{R}$ protein of a cell showing the granular distribution of the staining in the soma and dendrites (arrows) and in varicose processes (arrow- heads). B,E: $\mathrm{P} 2 \mathrm{X}_{2} \mathrm{R}$ mRNA. C,F: $\mathrm{P} 2 \mathrm{X}_{2} \mathrm{R}$ protein. D,G: Merge. Note the colocalization of $\mathrm{P} 2 \mathrm{X}_{2} \mathrm{R}$ protein and mRNA signals around the nucleus (D), proximal dendrites (D), and varicose processes (G). Scale bars $=$ $12 \mu \mathrm{m}$ in $\mathrm{A} ; 8 \mu \mathrm{m}$ in $\mathrm{B}-\mathrm{D} ; 6 \mu \mathrm{m}$ in $\mathrm{E}-\mathrm{G}$. study, $\mathrm{P} 2 \mathrm{X}_{2} \mathrm{R}$ expression in dendrites was confined to postsynaptic specializations, microtubules, mitochondria, and granules, whereas $\mathrm{P} 2 \mathrm{X}_{2} \mathrm{R}$ expression in axons was in synaptic contacts and in granular and in agranular vesicles of different sizes. For our material, confocal microscopy showed that varicose processes are positive for orexin and $\mathrm{P} 2 \mathrm{X}_{2} \mathrm{R}$ protein and mRNA, indicating a colocalization at presynaptic levels. For $\mathrm{P}_{2} \mathrm{X}_{2} \mathrm{R}$, this staining pattern has been previously described only for the nucleus tractus solitarius (Yao et al., 2001). For orexin, the presence of a high number of positive varicose axons and terminals throughout the brain is a very common finding (Nambu et 
al., 1999). Although we did not perform an electron microscopy investigation, and our study could not distinguish between varicose axons and terminals, the presence of both orexin and $\mathrm{P}_{2} \mathrm{X}_{2} \mathrm{R}$ in varicosities suggests the possibilities of functional interactions between the purinergic and the orexinergic systems at presynaptic levels.

The present study also shows, for the first time, localization of the $\mathrm{P} 2 \mathrm{X}_{2} \mathrm{R}$ mRNA in dendrites and axons. Dendritric/axonal mRNA localization and local translation are two important mechanisms to regulate gene expression and synaptic plasticity (Martin, 2004). mRNAs encoding olfactory marker proteins have been localized in axons of the olfactory bulb (Job and Eberwine, 2001), and mRNAs encoding for receptors such as GluR1 and GlyR have been detected in hippocampal dendrites (Racca et al., 1997; Kacharmina et al., 2000). So far, except for vasopressin and oxytocin, very few mRNAs encoding for neuropeptides have been detected in axons of hypothalamic neurons (Mohr and Richter, 2004). The present data extend these findings to the purinergic receptor system in the hypothalamic region. Thus, ATP-mediated excitation may act independently in different synaptic compartments of the same neurons where the receptor is synthesized locally.

In conclusion, the convergence of physiological (Wollmann et al., 2005) and anatomical (present study) data indicates that orexinergic hypothalamic neurons may be excited by ATP via activation of $\mathrm{P} 2 \mathrm{X}_{2} \mathrm{R}$. P2X $\mathrm{X}_{2} \mathrm{R}$-mediated ATP signaling must have a crucial role to play in the modulation of orexin neurons, insofar as all the orexincontaining neurons were found to express this receptor. The significance of this finding is not yet clear. One explanation is that ATP is coreleased in synaptic vesicles with several other neurotransmitters and can modulate their release (Cunha and Ribeiro, 2000; Khakh, 2001). Among these neurotransmitters, acetylcholine and noradrenaline are known to exert direct actions on orexin neurons (Burdakov, 2004; Bayer et al., 2005). Thus, ATP could exert two types of actions on orexin neurons: one direct through $\mathrm{P}_{2} \mathrm{X}_{2} \mathrm{R}$ activation and one indirect through modulation of neurotransmitters known to act on orexin neurons. Alternatively, ATP-signaling is crucial for neuronglia communication and for calcium homeostasis (Brookes et al., 2004). Different pathological conditions, such as head trauma or hypoxia, can induce dramatic increases of ATP concentrations (Ciccarelli et al., 2001) with subsequent activation of $\mathrm{P} 2 \mathrm{XR}$-expressing cells. Because $\mathrm{P} 2 \mathrm{X}_{2} \mathrm{R}$ potentiates responses at a lower $\mathrm{pH}$, such as during brain edema or ischemia, it has been stressed that orexin cells expressing $\mathrm{P}_{2} \mathrm{X}_{2} \mathrm{R}$ may represent the link between focal hypothalamic lesion and influences on the arousal system (Matsumoto et al., 2004; Wollmann et al., 2005). Thus, identification of the receptor subtype responsible for the ATP modulation of the orexin system may represent a key factor in the development of specific drugs able to modulate the complex functions mediated by orexin neurons.

\section{ACKNOWLEDGMENTS}

We are grateful to Dr. Andrea Viggiano for helpful suggestions, to Tilmann Achsel for critical reading of the manuscript, and to Francesca Ferrari for technical suggestions.

\section{LITERATURE CITED}

Bayer L, Eggermann E, Serafin M, Grivel J, Machard D, Muhlethaler M, Jones BE. 2005. Opposite effects of noradrenaline and acetylcholine upon hypocretin/orexin vs. melanin concentrating hormone neurons in rat hypothalamic slices. Neuroscience 130:807-811.

Brookes PS, Yoon Y, Robotham JL, Anders MW, Sheu SS. 2004. Calcium, ATP, and ROS: a mitochondrial love-hate triangle. Am J Physiol Cell Physiol 287:C817-C833.

Burdakov D. 2004. Electrical signaling in central orexin/hypocretin circuits: tuning arousal and appetite to fit the environment. Neuroscientist 10:286-291.

Ciccarelli R, Ballerini P, Sabatino G, Rathbone MP, D’Onofrio M, Caciagl F, Di Iorio P. 2001. Involvement of astrocytes in purine-mediated reparative processes in the brain. Int J Dev Neurosci 19:395-414.

Cunha RA, Ribeiro JA. 2000. ATP as a presynaptic modulator. Life Sci 68:119-137.

Eggermann E, Bayer L, Serafin M, Saint-Mleux B, Bernheim L, Machard D, Jones BE, Muhlethaler M. 2003. The wake-promoting hypocretinorexin neurons are in an intrinsic state of membrane depolarization. J Neurosci 23:1557-1562.

Ferguson AV, Samson WK. 2003. The orexin/hypocretin system: a critical regulator of neuroendocrine and autonomic function. Front Neuroendocrinol 24:141-150.

Florenzano F, Viscomi MT, Cavaliere F, Volonte C, Molinari M. 2002. Cerebellar lesion up-regulates $\mathrm{P} 2 \mathrm{X} 1$ and $\mathrm{P} 2 \mathrm{X}_{2} \mathrm{R}$ purinergic receptors in precerebellar nuclei. Neuroscience 115:425-434.

Florenzano F,Viscomi MT, Conversi D, Cabib S, Molinari M. 2003. P2X ${ }^{1,2}$ distribution in the rat forebrain: selective labelling of limbic structures by P2X ${ }^{1}$ subunit. Abstract, Washington, DC: Society for Neuroscience Online Program No. 251.4.

Florenzano F, Viscomi MT, Cavaliere F, Volonte C, Molinari M. 2006. The role of ionotropic purinergic receptors (P2X) in mediating plasticity responses in the central nervous system. In: Bähr M, editor. Brain repair. New York: Georgetown Eurekah/Landes Bioscience, Springer Science and Business Media. p 77-100.

Gurin VN, Gurin AV, Melenchuk EV, Spyer KM. 2003. The effects of activation and blockade of central P2X receptors on body temperature. Neurosci Behav Physiol 33:845-851.

Harris GC, Wimmer M, Aston-Jones G. 2005. A role for lateral hypothalamic orexin neurons in reward seeking. Nature 437:556-559.

Jo YH, Role LW. 2002. Coordinate Release of ATP and GABA at in vitro synapses of lateral hypothalamic neurons. J Neurosci 22:4794-4804.

Job C, Eberwine J. 2001. Localization and translation of mRNA in dendrites and axons. Nat Rev Neurosci 2:889-898.

Kacharmina JE, Job C, Crino P, Eberwine J. 2000. Stimulation of glutamate receptor protein synthesis and membrane insertion within isolated neuronal dendrites. Proc Natl Acad Sci U S A 97:11545-11550.

Kanjhan R, Housley GD, Burton LD, Christie DL, Kippenberger A, Thorne PR, Luo L, Ryan AF. 1999. Distribution of the $\mathrm{P}_{2} \mathrm{X}_{2} \mathrm{R}$ receptor subunit of the ATP-gated ion channels in the rat central nervous system. J Comp Neurol 407:11-32.

Khakh BS. 2001. Molecular physiology of P2X receptors and ATP signalling at synapses. Nat Rev Neurosci 2:165-174.

Khakh BS, Burnstock G, Kennedy C, King BF, North RA, Seguela P, Voigt M, Humphrey PP. 2001. International union of pharmacology. XXIV. Current status of the nomenclature and properties of P2X receptors and their subunits. Pharmacol Rev 53:107-118.

Koles L, Furst S, Illes P. 2005. P2X and P2Y receptors as possible targets of therapeutic manipulations in CNS illnesses. Drug News Perspect 18:85-101.

Loesch A, Miah S, Burnstock G. 1999. Ultrastructural localisation of ATPgated $\mathrm{P}_{2} \mathrm{X}_{2}$ receptor immunoreactivity in the rat hypothalamoneurohypophysial system. J Neurocytol 28:495-504.

Martin KC. 2004. Local protein synthesis during axon guidance and synaptic plasticity. Curr Opin Neurobiol 14:305-310.

Matsumoto N, Sorimachi M, Akaike N. 2004. Excitatory effects of ATP on rat dorsomedial hypothalamic neurons. Brain Res 1009:234-237.

Mileykovskiy BY, Kiyashchenko LI, Siegel JM. 2005. Behavioral correlates of activity in identified hypocretin/orexin neurons. Neuron 46:787-798.

Mochizuki T, Scammell TE. 2003. Orexin/hypocretin: wired for wakefulness. Curr Biol 13:R563-R564.

Mohr E, Richter D. 2004. Subcellular vasopressin mRNA trafficking and local translation in dendrites. J Neuroendocrinol 16:333-339. 
Monda M, Viggiano A, De Luca V. 2003. Paradoxical effect of orexin A: hypophagia induced by hyperthermia. Brain Res 961:220-228.

Nambu T, Sakurai T, Mizukami K, Hosoya Y, Yanagisawa M, Goto K. 1999. Distribution of orexin neurons in the adult rat brain. Brain Res 827:243-260.

North RA. 2002. Molecular physiology of P2X receptors. Physiol Rev 82: 1013-1067.

Paxinos G. 2004. The rat nervous system, 3rd ed. Oxford, United Kingdom: Elsevier Academic Press.

Paxinos G, Watson C. 1994. The rat brain in stereotaxic coordinates. Sydney: Academic Press.

Petralia RS, Wenthold RJ. 1992. Light and electron immunocytochemical localization of AMPA-selective glutamate receptors in the rat brain. J Comp Neurol 318:329-354.

Petralia RS, Yokotani N, Wenthold RJ. 1994. Light and electron microscope distribution of the NMDA receptor subunit NMDAR1 in the rat nervous system using a selective anti-peptide antibody. J Neurosci 14:667-696.

Peyron C, Tighe DK, van den Pol AN, de Lecea L, Heller HC, Sutcliffe JG, Kilduff TS. 1998. Neurons containing hypocretin (orexin) project to multiple neuronal systems. J Neurosci 18:9996-10015.

Racca C, Gardiol A, Triller A. 1997. Dendritic and postsynaptic localizations of glycine receptor alpha ásubunit mRNAs. J Neurosci 17:16911700.

Robertson SJ, Ennion SJ, Evans RJ, Edwards FA. 2001. Synaptic P2X receptors. Curr Opin Neurobiol 11:378-386.

Sakurai T. 2003. Orexin: a link between energy homeostasis and adaptive behaviour. Curr Opin Clin Nutr Metab Care 6:353-360.

Saper CB, Chou TC, Scammell TE. 2001. The sleep switch: hypothalamic control of sleep and wakefulness. Trends Neurosci 24:726-731.

Scammell TE, Saper CB. 2005. Orexin, drugs and motivated behaviors. Nat Neurosci 8:1286-1288.

Schadlich H, Wirkner K, Franke H, Bauer S, Grosche J, Burnstock G, Reichenbach A, Illes P, Allgaier C. 2001. P2X(2), P2X(2-2) and P2X(5) receptor subunit expression and function in rat thoracolumbar sympathetic neurons. J Neurochem 79:997-1003.

Simon J, Kidd EJ, Smith FM, Chessell IP, Murrell-Lagnado R, Humphrey PP, Barnard EA. 1997. Localization and functional expression of splice variants of the $\mathrm{P}_{2} \mathrm{X}_{2} \mathrm{R}$ receptor. Mol Pharmacol 52:237-248.

Stojilkovic SS, Tomic M, He ML, Yan Z, Koshimizu TA, Zemkova H. 2005. Molecular dissection of purinergic P2X receptor channels. Ann N Y Acad Sci 1048:116-130.

Sutcliffe JG, de Lecea L. 2002. The hypocretins: setting the arousal threshold. Nat Rev Neurosci 3:339-349.

Tachibana M, Wenthold RJ, Morioka H, Petralia RS. 1994. Light and electron microscopic immunocytochemical localization of AMPAselective glutamate receptors in the rat spinal cord. J Comp Neurol 344:431-454.

Thakkar MM, Winston S, McCarley RW. 2002. Orexin neurons of the hypothalamus express adenosine A1 receptors. Brain Res 944:190194.

Viscomi MT, Florenzano F, Conversi D, Bernardi G, Molinari M. 2004. Axotomy dependent purinergic and nitrergic co-expression. Neuroscience 123:393-404.

Vulchanova L, Arvidsson U, Riedl M, Wang J, Buell G, Surprenant A, North RA, Elde R. 1996. Differential distribution of two ATP-gated channels (P2X receptors) determined by immunocytochemistry. Proc Natl Acad Sci U S A 93:8063-8067.

Wollmann G, Acuna-Goycolea C, Van Den Pol AN. 2005. Direct excitation of hypocretin/orexin cells by extracellular ATP at P2X receptors. J Neurophysiol 94:2195-2206.

Xiang Z, Bo X, Oglesby I, Ford A, Burnstock G. 1998. Localization of ATP-gated $\mathrm{P}_{2} \mathrm{X}_{2} \mathrm{R}$ receptor immunoreactivity in the rat hypothalamus. Brain Res 813:390-397.

Yao ST, Gourine AV, Spyer KM, Barden JA, Lawrence AJ. 2003. Localisation of $\mathrm{P}_{2} \mathrm{X}$ receptor subunit immunoreactivity on nitric oxide synthase expressing neurones in the brain stem and hypothalamus of the rat: a fluorescence immunohistochemical study. Neuroscience 121:411419 